\title{
BRINGING DU BOIS BACK IN
}

\section{American Sociology and The Morris Enunciation}

\author{
Lawrence D. Bobo \\ Department of African and African American Studies and Department of Sociology, \\ Harvard University
}

\begin{abstract}
Aldon D. Morris, The Scholar Denied: W. E. B. Du Bois and the Birth of Modern Sociology, Oakland, CA: University of California Press, 2015, 282 pages, ISBN 978-0-520-27635-2. \$29.95
\end{abstract}

The resurrection of W. E. B. Du Bois as a pioneering social scientist foundational to the field of sociology is a project that has been underway, arguably, for at least three decades (Bobo 2007). One important entry in this intellectual project came with the publication by the University of Chicago Press, in its "Heritage of Sociology Series," under the general editorship of Morris Janowitz, of the book Black Sociologists: Historical and Contemporary Perspectives (Blackwell and Janowitz, 1974). The volume featured major essays on W. E. B. Du Bois as well as on E. Franklin Frazier and Charles S. Johnson and chapters from a number of leading African American scholars (e.g., Walter Wallace, William Julius Wilson). Around this same time others were also pressing the case that the early and innovative work of Du Bois, in particular, had been grievously overlooked by sociologists (Green and Driver, 1976; Key 1978; Pettigrew 1980; Rudwick 1969).

A number of other significant publications helped to turn the tide by excavating anew Du Bois's contributions and highlighting the lasting and multidisciplinary reach of his efforts. Particularly worthy of attention for the social sciences are two edited volumes spearheaded by scholars at the University of Pennsylvania, one effort led by historians and another by sociologists. Michael B. Katz's and Thomas J. Sugrue's (1998) volume focused analytical attention on Du Bois's The Philadelphia Negro ([1899] 2007) and featured nine chapters, two by sociologists. The chapters explored the economic, political, and cultural context in which Du Bois launched and conducted his work as well as important legacies of his findings and perspective. Two years later, pivoting off of Du Bois's 1898 essay "The Study of Negro Problems," a special issue of the Annals (Anderson and Zuberi, 2000) contained twenty new essays and featured a more interdisciplinary range of scholars including economists, political scientists, anthropologists, gender studies and literature scholars, as well as philosophers. 
Building upon and significantly extending these many worthy efforts, Aldon Morris's The Scholar Denied authoritatively re-writes the conventional script of the origin of American sociology. The real foundation stone of sociological research in the United States is neither Robert E. Park and the Chicago school nor Frank Giddings and Columbia sociology, but rather, W. E. B. Du Bois and the Atlanta school. Morris's claim and achievement here will come as vindication in the eyes of some sociologists, a great but not unwelcome surprise to many others, and probably a bitterly contested assertion to more than a few. Let the debate begin. This well-crafted, meticulously researched, and theoretically serious work will command engagement from the discipline writ large. And given the rigor and sophistication of the work Morris has done, I have little doubt that his position will, like Du Bois himself, ultimately prevail.

In reflecting on these and many other recent efforts to bring Du Bois back in (Bulmer 1991; Edwards 2006; Itzigsohn and Brown, 2015; Prasch 2008; Williams 2006; Zuberi 2000), one cannot escape the question that comes to be at the heart of The Scholar Denied: Why was it necessary to engage in a long, fitful, and protracted effort to bring Du Bois back into the mainstream of sociological thinking? Why wasn't he comfortably perched there from the beginning? The short answer, according to Morris, is that Du Bois was systematically and deliberately marginalized. For Morris, this marginalization cannot be understood outside the context of a social milieu of anti-Black racism and the effects of that context on the perspectives and practices of dominant White sociologists.

A personal anecdote can help clarify and sharpen the tangible effects of the point made here. At the time of its publication, I shared my own article in the 2000 Annals issue on "The Study of African American Problems" (Bobo 2000) with two very senior White scholars of race relations and racial attitudes. Quite independent of one another, these two eminent individuals offered almost identical remarks of bewildered surprise that Du Bois had conducted serious research at such an early point, in their own domain of deep expertise, with which they were essentially completely unfamiliar. To paraphrase a bit, they each said (actually using almost identical words), "Interesting. I had no idea Du Bois had done such serious work. I always thought of him as a kind of worldly propagandist/activist on race issues who left the U.S. in alienation." Such a read from two serious scholars of race relations is indicative of how thoroughly Du Bois qua important and innovative sociologist had been wiped from collective memory among some sectors of the elite social scientific canon of race relations scholarship.

Of course, the marginalization of research focusing on minority populations and particularly that done by minority scholars is neither entirely a problem of the past nor an ill afflicting only sociology. According to political scientist Michael Dawson "One pernicious and all too common variant on this set of practices is the systematic and willful ignoring of the work of minority scholars... The complaint is not about knowing what is necessary to do decent work in one's field; that is a reasonable minimum expectation. The complaint is about the systematic refusal of some white scholars to confront the work of established minority scholars within their fields" (Dawson 2000, p. 356). Specifically with respect to much work on American political behavior and public opinion, Melissa Harris-Perry concluded that African Americans were often totally absent as social actors deemed of relevance to the political processes and outcomes under study and of no relevance to the theoretical ideas and body of research brought to bear on explaining and understanding the dynamics of race in much political science scholarship. As she put it: "African Americans are rendered irrelevant or invisible in the study of race politics in two ways: (a) through a failure to account for Black agency in affecting White attitudes, and (b) through a refusal of scholars of race to grapple with the literature on Black public opinion" (Harris-Lacewell 2003, p. 227). 
Yet the omission is particularly egregious in the case of Du Bois, a point Morris drives home persuasively. Du Bois published The Philadelphia Negro ([1899] 2007) at roughly the same moment that Emile Durkheim published his classic study Suicide (1897) and at the point that sociology departments were being established at the University of Chicago (1892) and at Columbia (1894). Given his training, the quality and innovativeness of his work, and the vigor of his early research program, Du Bois should be an obvious presence, speaking metaphorically, on the Mt. Rushmore of American sociology. Yet he is not. Explicating the gravity of this error, its completeness, and its sources is Morris's core project.

The sophistication, innovation, quality, and timing of Du Bois's early sociological work constitute the first element of Morris's case for regarding Du Bois as America's $U r$-sociologist, the origin point of the discipline. As Morris explains: "Indeed, Du Bois emerged from The Philadelphia Negro as the first number-crunching, surveying, interviewing, participant-observing, and field-working sociologist in America, a pioneer in the multimethods approach. He cross-checked his quantitative and qualitative data to ensure accuracy by eradicating undetected errors associated with a particular method. Thus he also pioneered the data-gathering technique known as triangulation" (p. 47). These methodological advances, Morris stresses, were undertaken by Du Bois at a point when Robert Park, "four years older than Du Bois [and with] few professional accomplishments" (Morris 2015, p. 100) was seeking to attach himself to Booker T. Washington.

A second critical element in Morris's analysis is the way in which Robert Park and other founding members of the Chicago school marginalized and presided over steadily writing Du Bois out of the sociological canon. The tale as Morris tells it begins by noting the enormous reach and influence of Booker T. Washington, who would eventually become Du Bois's nemesis. While the Du Bois-Washington feud is a tale twice told, far less familiar is the fact that Robert E. Park worked for years as Washington's assistant and ghost writer at the Tuskegee Institute. In many respects, Park carried forward Washington's accommodationist stance and view of the position of Blacks as well as his antagonism toward Du Bois. Morris shows that this antagonism reached so far as to involve trying to publicly vilify Du Bois in the wake of the Atlanta Race riot of 1906.

Morris goes further than this, however, showing that Du Bois was increasingly written out of an understanding of the origins of sociological theory and research in the United States by Park and others at the University of Chicago and throughout the discipline. The sin here is not merely one of failing to acknowledge the timing and quality of Du Bois's research, Morris suggests, but also one of (mis) appropriation of Du Boisian ideas and insights. For example, Park's notions of the "marginal man" seemingly owed much to Du Bois's pathbreaking argument about "double consciousness," a debt that Park left effectively unacknowledged. Morris concludes with a strong indictment:

Given the entire record, this conclusion is inescapable: Park and the Chicago school locked Du Bois out of the intellectual fraternity of sociology by systematically ignoring his scholarship. This exclusion relegated Du Bois to the institutional margins of American sociology because it was accompanied by his exclusion from scholarly networks that functioned as pathways to journal editorships, memberships in learned societies, and presidency of learned societies, including the American Sociological Society. Because of his skin color and his challenges to Park's racist propositions Du Bois was denied meaningful participation in mainstream sociology (2015, p. 141). 
In short, Park and others were actively complicit in the discriminatory and racist bias characteristic of their times.

A third element of Morris's account concerns Du Bois's influence on Max Weber. It is frequently claimed that while in Germany Du Bois "studied with Weber." Morris provides a significant correction to this well-rehearsed narrative. Du Bois and Weber really first crossed paths with one another when the former was twenty-four and the latter twenty-eight years old, as status equals, as graduate students, not as pupil and instructor. Furthermore and in contradistinction to the standard narrative, Morris builds a creditable case that Du Bois did far more to shape the thinking of the young Weber than Weber ever did to shape the thinking of the young Du Bois. Both Du Bois and Weber were taking in lessons from the likes of Gustav von Schmoller and other prominent German intellectuals of the day. As Morris explains, "In Germany, Du Bois and Weber were taught by many of the same professors, were mentored by the same scholars of the German historical school of economics, and involved in many of the same intellectual activities..." (p. 152). Later, Weber actually solicits an article from Du Bois to publish in his journal the Arvchiv fur Sozialwissenschaft and Sozialpolitik. Moreover, Morris points to how Du Bois's theoretical analysis of how the projects of imperialism, colonialism, and capitalism were shaping European exploitation of people of color in the United States and around the world came to profoundly affect Weber's own thinking about dynamics on the European continent, particularly concerning what was then termed "the Polish problem." The German scholar showed an eagerness to bring Du Bois into the mainstream while he was being largely ostracized by White American sociology at home.

The fourth element in Morris's account is his effort to elevate the tradition of work Du Bois and his collaborators and students launched to the status of a recognized school of sociological work, namely the Du Bois-Atlanta school. Morris is certainly able to show that Du Bois and his Atlanta University collaborators produced significant and high quality scholarship for a number of years. Save for the socially imposed peripheral place of a Historically Black College in the higher educational hierarchy and the profoundly de-limited access to financial support for their work, the scholars of the Du Bois-Atlanta school of Sociology he deems worthy of recognition as such. Du Bois certainly affected the work of other Black sociologists of the day, such as Monroe Work and Richard Wright, and staged a number of important topical Atlanta Conferences and subsequent publications focusing on major arenas of social life within Black communities.

A fifth element of Morris's analysis involves, in effect, throwing down the gauntlet before the field of sociology itself. Morris's book, ultimately, represents a genuine intellectual and moral challenge for sociology in the United States. Morris thus argues: "Here we reach the crux: invisibility and recognition are opposites. Because of the color line, white social scientists did not recognize Du Bois's scientific contributions as original, rare, and distinctive. As a black person, Du Bois was largely invisible, as were his pioneering scientific contributions" (p. 184). Morris thereby openly contests, in a powerful way, what those to whom I refer as "the Keepers of the Canon" regard as the core works, concepts, theories, and figures of American sociology. The great test here for the future is whether the Keepers of the Canon come to fully acknowledge the profoundly distorting impact of the racism of the past on how we think about and do sociology even today and, especially, whether they too now work to undo both this shameful legacy and it's enduring effects on the culture and practices of the discipline itself.

Morris's analysis prompts one to speculate, for example, whether sociology as a discipline would have so completely failed to anticipate the emergence of a potent civil rights movement in the 1960s if Du Boisian theory had been taken more seriously. 
In his Presidential address to the American Sociological Association in 1963, Everett C. Hughes interrogated the discipline's failure, despite its many examinations of "the Negro problem," to forecast one of the most significant social movements in American history (Hughes 1963). Yet even this otherwise probing reflection on a major failure of the "sociological imagination" fails to cite Du Bois even once. Might direct engagement with a Du Boisian perspective which stresses looking carefully at the internal organization and dynamics of Black social life, the moral agency and conscious action of Blacks themselves, and the fundamental and irreducible humanity of Black people have saved the discipline from this yawning intellectual failure?

The Scholar Denied is not without some limitations. For example, there are points where careful documentation of his claims seems a bit incomplete. Morris meticulously documents how Du Bois disappeared from early treatises on sociology in later editions of important works by figures at Chicago. Yet, for his all-important claim that Du Bois shaped Weber's theoretical formulations, this claim rests not on direct evidence of Weber citing the work of Du Bois in his own writings, but instead on Weber's move away from racist ideas dominant among German scholars at the time, particularly after his visit with Du Bois in the United States in 1904, and on the record of a prominent scholarly public debate where Weber did explicitly refer to and praise Du Bois. The evidence of influence on Weber is thus a bit more inferential (though not unreasonable) than it is direct. Similarly, if the discriminatory barriers faced by Du Bois were so extreme, it is something of a puzzle exactly how and why he was able to get so many prominent White scholars of the day to take part in his Atlanta conferences over the years. There may also be some tendency to read the tastes and prevailing views of our times into the Du Bois writings. For example, Morris takes to task some prominent scholars who faulted Du Bois as often patronizing and elitist in his discussion of working class and poor Blacks. Some of these critiques (Berry 2000; Cohen 2004) still seem cogent and are not directly engaged by Morris. These several concerns, in fairness, rank more as a wish that Morris had provided fuller detail, documentation, and direct answers on some points than they do a tally of serious shortcomings of the work.

Within some subfields of the discipline Du Bois is already accorded a central and prominent place. Efforts at theory development in race studies in sociology openly acknowledge a debt to Du Bois (Winant 2000). Likewise, sociological students of urban social dynamics recognize a debt to Du Bois (Hunter 2013; Loughran 2015). Political philosophy is, similarly, a site of vigorous scholarly engagement with Du Bois's thought and research (Balfour 2011; Gooding-Williams 2009; as well as the related symposium published in Du Bois Review: Social Science Research on Race in 2011). But Morris's work arguably presses these trends to new heights.

From my vantage point, The Scholar Denied is a must read for all broad-minded individuals who regard themselves as well-informed about social science in the United States; if not for its convincing resurrection of Du Bois's foundational contribution to American sociology, then for its case study of the role of larger societal patterns of politics, bias, and power in the making of what comes to be regarded as important scientific knowledge and contributions. Morris's book should be required reading for every student entering graduate sociology $\mathrm{PhD}$ programs. Moreover, The Scholar Denied should occupy a space next to Weber's (1930) The Protestant Ethic and the Spirit of Capitalism on the list of required readings in Introduction to Sociology classes around the country: The sins of omission of the past are that great, the quality of what I shall characterize as "The Morris Enunciation" is that high, and the legacy of the marginalization of the contributions of minority scholars remain that troublingly far from complete eradication.

Du Bois told us long ago that the color line would be the bane of the twentieth century. As is plain enough now, however, the African American journey to full 
membership in the U.S. economy, polity, and culture is still palpably incomplete as we move into the second decade of the twenty-first century (Berry 2000; Bobo 2011) and find ourselves compelled to shout that "Black Lives Matter!". Du Bois's analysis of race identified the profound, multidimensional impact of constructing a social order wherein color and class were merged in defining who had access to power, wealth, and privilege and who did not. He tried to make it clear to scholars that those who are the targets of prejudice were also those most often shunted to the lowest levels of poverty and economic despair. As such, Du Bois saw class and race as constitutionally and profoundly fused in the make-up and dynamics of social life. And he maintained that scholarship could either distort understanding of these conditions and processes by yielding to prevailing ideology and bias or it could strive for an historically and contextually grounded and empirically rigorous analysis of the interaction of class and racial inequality in the structuring of the American social order.

The depth and power of Du Bois's contribution to social science is arguably still not fully appreciated. But Aldon Morris's The Scholar Denied takes an enormous and sure-footed stride toward righting a great historic wrong. American sociology and sociologists failed to acknowledge Du Bois as the fountainhead of the discipline in his day. Finally now, perhaps, he will be recognized as a true Colossus of the development of American sociology. Aldon Morris's stentorian enunciation brings Du Bois back into the theoretical and methodological mainstreams of the discipline, right where he has always belonged.

\section{ACKNOWLEDGMENT}

I wish to thank Matthew Clair for comments and suggestions on an earlier draft.

\section{REFERENCES}

Anderson, Elijah, and Tukufu Zuberi (Eds.) (2000). The Study of African American Problems: W. E. B. Du Bois's Agenda, Then and Now. Annals of the American Academy of Political and Social Science, 568 (March): 1-316.

Balfour, Lawrie (2011). Democracy's Reconstruction: Thinking Politically with W. E. B. Du Bois. New York: Oxford University Press.

Berry, Mary Frances (2000). Du Bois as Social Activist: Why We Are Not Saved. Annals of the American Academy of Political and Social Science, 568 (March): 100-110.

Blackwell, James E., and Morris Janowitz (Eds.) (1974). Black Sociologists: Historical and Contemporary Perspectives. Chicago, IL: University of Chicago Press.

Bobo, Lawrence D. (2000). Reclaiming a Du Boisian Perspective on Racial Attitudes. Annals of the American Academy of Political and Social Science, 568 (March): 186-202.

Bobo, Lawrence D. (2007). Introduction. In Henry Louis Gates, Jr. (Ed.) The Oxford W. E. B. Du Bois. The Philadelphia Negro: A Social Study by W. E. B. Du Bois, pp. xxv-xxx. New York: Oxford University Press.

Bobo, Lawrence D. (2011). An American Conundrum: Race, Sociology, and the African American Road to Citizenship. In Henry Louis Gates, Jr., Claude Steele, Lawrence D. Bobo, Michael C. Dawson, Gerald Jaynes, Lisa Crooms-Robinson, and Linda Darling-Hammond (Eds.) The Oxford Handbook of African American Citizenship, 1865-Present, pp. 19-70. New York: Oxford University Press.

Bulmer, Martin (1991). W. E. B. Du Bois as a Social Investigator: The Philadelphia Negro, 1899. In Martin Bulmer, Kevin Bales, and Kathryn Kish Sklar (Eds.) The Social Survey In Historical Perspective, 1880-1940, pp. 170-187. New York: Cambridge University Press.

Cohen, Cathy J. (2004). Deviance as Resistance: A New Research Agenda for the Study of Black Politics. Du Bois Review: Social Science Research on Race, 1(1): 27-46.

Dawson, Michael C. (2000). Slowly Coming to Grips with the Effects of the American Racial Order on American Policy Preferences. In David O. Sears, Jim Sidanius, and Lawrence D. Bobo (Eds.) Racialized Politics: The Debate on Racism in America, pp. 344-358. Chicago, IL: University of Chicago Press. 
Du Bois, W. E. B. ([1899] 2007). The Philadelphia Negro: A Social Study. New York: Oxford University Press.

Edwards, Barrington S. (2006). W. E. B. Du Bois: Berlin, Empirical Social Research, and the Race Question. Du Bois Review: Social Science Research on Race, 3(2): 395-424.

Gooding-Williams, Robert (2009). In The Shadow of Du Bois: Afro-Modern Political Thought in America. Cambridge, MA: Harvard University Press.

Green, Dan S., and Edwin Driver (1976). W. E. B. Du Bois: A Case in the Sociology of Sociological Negation. Phylon, 37: 308-333.

Harris-Lacewell, Melissa V. (2003). The Heart of the Politics of Race: Centering Black People in the Study of White Racial Attitudes. Fournal of Black Studies, 34(2): 222-249.

Hughes, Everett C. (1963). Race Relations and the Sociological Imagination. American Sociological Review, 28(6): 879-890.

Hunter, Marcus Anthony (2013). Black Citymakers: How The Philadelphia Negro Changed Urban America. New York: Oxford University Press.

Itzigsohn, Jose, and Karida Brown (2015). Sociology and the Theory of Double Consciousness: W. E. B. Du Bois's Phenomenology of Racialized Subjectivity. Du Bois Reviezv: Social Science Research on Race. 12(2): 231-248.

Katz, Michael B., and Thomas J. Sugrue (Eds.) (1998). W. E. B. Du Bois, Race, and the City: The Philadelphia Negro and Its Legacy. Philadelphia, PA: University of Pennsylvania Press.

Key, R. Charles (1978). Society and Sociology: The Dynamics of Black Sociological Negation. Phylon, 39: 35-38.

Loughran, Kevin (2015). The Philadelphia Negro and the Canon of Classical Urban Theory. Du Bois Review: Social Science Research on Race, 12(2): 249-267.

Pettigrew, Thomas F. (Ed.) (1980). The Sociology of Race Relations: Reflection and Reform. New York: The Free Press.

Prasch, Robert E. (2008). W. E. B. Du Bois's Contributions to U.S. Economics (1893-1910). Du Bois Review: Social Science Research on Race, 5(2): 309-324.

Rudwick, Eliot (1969). Note on a Forgotten Black Sociologist: W. E. B. Du Bois and the Sociological Profession. American Sociologist, 4: 303-306.

Weber, Max (1930). The Protestant Ethic and the Spirit of Capitalism. London: George Allen \& Unwin Ltd.

Williams, Robert W. (2006). The Early Social Science of W. E. B. Du Bois. Du Bois Review: Social Science Research on Race, 3(2): 365-394.

Winant, Howard (2000). Race and Race Theory. Annual Review of Sociology, 26: 169-185.

Zuberi, Tukufu (2000). Deracializing Social Statistics: Problems in the Quantification of Race. Annals of the American Academy of Political and Social Science, 568 (March): 172-185. 